\title{
PENDEKATAN PEMBELAJARAN TEMATIK DENGAN MENGGUNAKAN VIDEO DAN KEMAMPUAN SPASIAL VISUAL TERHADAP HASIL BELAJAR MATEMATIKA
}

\author{
Jamahi Saragih ${ }^{1}$ dan Efendi Napitupul \\ Guru Kelas SD Negeri 067245 Medan Selayang ${ }^{1}$ dan Universitas Negeri Medan ${ }^{2}$ \\ Jamahis@yahoo.com ${ }^{1}$ dan napitupuluefendi@gmail.com ${ }^{2}$
}

\begin{abstract}
Abstrak: Penelitian ini bertujuan untuk mengetahui: (1) hasil belajar matematika yang diajar dengan pendekatan pembelajaran tematik dengan mengunakan video lebih tinggi dari pada siswa yang diajar dengan pendekatan pembelajaran tematik dengan menggunakan grafis konvensional, (2) hasil belajar matematika siswa yang memiliki kemampuan Spasial Visual tinggi lebih tinggi dari pada siswa yang memiliki kemampuan Spasial Visual rendah. (3) ada interaksi pendekatan pembelajaran tematik dengan menggunakan video dan kemampuan Spasial Visual terhadap hasil belajar matematika siswa. Metode penelitian menggunakan metode quasi eksperimen dengan desain penelitian faktorial $2 \times 2$. Teknik analisis data menggunakan ANAVA dua jalur pada taraf signifikan $\alpha=0,05$. Hasil penelitian menunjukan bahwa: (1) hasil belajar matematika yang diajar dengan pendekatan pembelajaran tematik dengan mengunakan video lebih tinggi dari pada siswa yang diajar dengan pendekatan pembelajaran tematik dengan menggunakan grafis konvensional (2) hasil belajar matematika siswa yang memiliki kemampuan Spasial Visual tinggi lebih tinggi dari pada siswa yang memiliki kemampuan Spasial Visual rendah (3) ada interaksi pendekatan pembelajaran tematik dengan menggunakan media (video, grafis konvensional) dan kemampuan Spasial Visual terhadap hasil belajar matematika.
\end{abstract}

Kata Kunci: Pendekatan Pembelajaran Tematik Dengan Menggunakan Vide dan Grafis Konvensional, Kemampuan Spasial Visual, Hasil Belajar Matematika

Abstract: This study aimed to determine: (1) learning outcomes are taught mathematics by a thematic approach to learning by using video higher than the students who are taught with thematic learning approach using conventional graphics, (2) mathematics learning outcomes of students who have high ability of Visual Spatial higher than the students who have the Visual Spatial ability is low, (3) there is no interaction with the thematic approach to learning using video and Visual spatial ability on learning outcomes of students' mathematics. The research method using quasi-experimental research design with $2 \times 2$ factorial ANOVA Analysis using two lines at $\alpha$ $=0.05$ significance level. The results showed that: (1) learning outcomes are taught mathematics by a thematic approach to learning by using video higher than the students who are taught with thematic learning approach using conventional graphics (2) mathematics learning outcomes of students who have a high Visual Spatial ability is higher of the students who have the ability to lower the Visual Spatial (3) no interaction thematic approach to learning by using media (video, graphics conventional) and the Visual Spatial abilities against the learning outcomes of mathematics.

Keywords: Thematic Learning Approach Using Conventional Vide and Graphics, Visual Spatial Ability, Mathematics Learning Outcomes.

\section{PENDAHULUAN}

Sekolah Dasar (SD) adalah jenjang paling dasar pada pendidikan formal di Indonesia. SD ditempuh dalam waktu 6 tahun, mulai dari kelas 1 sampai kelas 6. Lulusan sekolah dasar dapat melanjutkan pendidikan ke Sekolah Menengah Pertama (atau sederajat). Pelajar sekolah dasar umumnya berusia 7-12 tahun. Di Indonesia, setiap warga negara berusia 7-15 tahun wajib mengikuti pendidikan dasar, yakni sekolah dasar (atau sederajat) 6 . Sekolah dasar diselenggarakan oleh pemerintah maupun swasta.

Dalam Undang-undang Sistem Pendidikan Nasional (UU Nomor 20 Tahun 
2001) Pasal 17 mendefinisikan pendidikan dasar sebagai berikut: Pendidikan dasar merupakan jenjang pendidikan yang melandasi jenjang pendidikan menengah.

Peningkatan mutu pembelajaran di sekolah akan selalu mendapatkan perbaikanperbaikan secara berkelanjutan. Perbaikan dan penyempurnaan pembelajaran di sekolah itu, dilakukan melalui perubahan kurikulum sekolah oleh pemerintah. Kurikulum itu memang bersifat dinamis, harus selalu menyesuaikan dengan perkembangan ilmu pengetahuan. Di samping itu melalui berbagai observasi dan evalasi pendidikan, masukan dari para pakar pendidik serta masukan dari masyarakat yang peduli pendidikan, pemerintah berusaha untuk memperbaiki kurikulum itu yang mereka pandang perlu untuk diadakan perbaikan dan penyempurnaan.

Meskipun masyarakat banyak yang mengasumsikan,bahwa setiap ganti menteri mesti ganti kurikulum. Sebagai sorang guru yang professional, sudah seharusnya cepat merespon perubahan kurikulum. Perubahan kurikulum yang terjadi merupakan hal yang biasa dan merupakan suatu keniscayaan dalam rangka mengikuti perkembangan masyarakat yang begitu cepat.

Dalam rencana penerapan kurikulum di sekolah dasar disajikan model pembelajaran tematik integratif. Kurikulum tematik integratif yaitu menerapkan pola tematik integratif, dengan pola penerapan tema yang sama seluruh Indonesia, sedangkan guru dan sekolah hanya berperan mengembangkan materi sesuai dengan tema yang sudah ada.

Kurikulum tematik integratif menuntut guru untuk lebih bisa mengembangkan cara pembelajaran yang asyik dan menyenangkan sesuai kebutuhan dan perkembangan keadaan. Proses ini mungkin tidak akan serta merta berubah dalam diri guru yang selama ini biasa "mencekoki" siswa dengan penjelasanpenjelasan gaya satu arah.

Oleh karena itu, guru harus bisa memposisikan diri sebagai pembimbing siswa bukan sang otoriter kelas. Masalah bakat dan minat, hanya siswa sendiri yang bisa mengenali dirinya sendiri. Inilah konsep kurikulum tematik integratif yang lebih "memanusiakan manusia". Bukan menjadikan siswa "robot pendidikan" yang cepat lelah dan pusing karena harus mengerjakan tugas sekolah bejibun, belum lagi aneka buku yang harus dia bawa di tas karena banyaknya pelajaran yang harus dia pelajari.
Guru diharapkan mampu menggali dan memancing potensi siswa, apapun minat dan bakatnya. Siswa sendiri menjadi obyek yang diberi keleluasaan untuk mengembangkan potensi dirinya. Dengan demikian, tidak ada lagi dikotomi (kasta) mata pelajaran yang menyebabkan munculnya label seorang anak disebut "pintar" atau "kurang pintar" dengan berpatokan pada mata pelajaran tertentu yang dianggap memiliki nilai tersendiri. Mau pelajaran sains, sosial, atau bahasa semua sama "haknya" yang bebas dipilih oleh siswa. Tentunya hal ini menimbulkan ekses lain, salah satunya dengan persiapan sumber daya manusia (guru) dan infrastruktur yang mendukung bagi perkembangan siswa dan sekolah.

Anak cerdas merupakan dambaan setiap orang, sebab kemampuan merupakan modal anak untuk mengarungi kehidupan di masa mendatang. Kemampuan adalah kemampuan seseorang untuk mengingat, kemampuan memahami, memahami dunia, mengingat, kreativitas tinggi, imanjinasi yang berkembang B. Uno (2006:58) Banyak ahli yang sepakat mengatakan bahwa semua anak pada dasarnya cerdas. Gardner (1993) dalam B. Uno (2009:11). Kemampuan seseorang meliputi unsur-unsur kemampuan matematika logika, kemampuan bahasa, kemampuan musikal, kemampuan visual spasial, kemampuan kinestetis, kemampuan interpersonal, kemampuan intrapersonal dan kemampuan naturalis.

Wijanarko (2012:48) Kemampuan atau kepandaian itu aspeknya banyak, beberapa aspek kemampuan dalam diri seseorang secara bersama-sama membangun level kemampuan orang tersebut, dan sekaligus membuat kepribadian seseorang menjadi sangat unik dan tidak akan ada yang sama persis, sekalipun dia anak kembar. Dalam kemampuan visual spasial diperlukan adanya pemahaman kiri-kanan, pemahaman perspektif, bentuk-bentuk geometris, menghubungkan konsep spasial dengan angka, kemampuan dalam mentransformasi mental dari bayangan visual.

Faktor-faktor tersebut juga diperlukan dalam belajar matematika. Peranan kemampuan spasial terhadap matematika Amstrong (2013:25) geometri lebih mudah dari pada aljabar. Dalam geometri terdapat unsur penggunaan visualisasi, penalaran spasial dan pemodelan. Hal ini menunjukkan bahwa kemampuan spasial merupakan tuntutan kurikulum yang harus diakomodasi dalam pembelajaran di kelas. Dalam kurikulum 
nasional di Indonesia, dari tingkat sekolah dasar sampai perguruan tinggi siswa/mahasiswa dituntut untuk dapat menguasai materi geometri bidang dan geometri ruang yang notabene juga membutuhkan kemampuan spasial.

Pendekatan tematik dalam pembelajaran memiliki kriteria dalam pendekatan tematik integratif, yaitu materi pembelajaran menggunakan pada fakta atau fenomena yang dapat dijelaskan dengan logika atau penalaran tertentu bukan sebatas kira-kira, khayalan, legenda, atau dongeng semata. Penjelasan guru, respon siswa, dan interaksi edukatif guru-siswa terbebas dari prasangka yang serta-merta, pemikiran subjektif, atau penalaran yang menyimpang dari alur berpikir logis. Mendorong dan menginspirasi siswa berpikir secara kritis, analistis, dan tepat dalam mengidentifikasi, memahami, memecahkan masalah, dan mengaplikasikan materi pembelajaran.

Mendorong dan menginspirasi siswa mampu berpikir hipotetik dalam melihat perbedaan, kesamaan, dan tautan satu sama lain dari materi pembelajaran. Mendorong dan menginspirasi siswa mampu memahami, menerapkan, dan mengembangkan pola berpikir yang rasional dan objektif dalam merespon materi pembelajaran. Menggunakan pada konsep, teori, dan fakta empiris yang dapat dipertanggungjawabkan. Tujuan pembelajaran dirumuskan secara sederhana dan jelas, namun menarik sistem penyajiannya.

\section{METODE}

Penelitian ini dilakukan di Sekolah Dasar Negeri Kota Medan. Perlakuan penelitian ini berlangsung selama 9 kali pertemuan dan disesuaikan dengan kalender pendidikan untuk pelaksanaan perlakuan dalam bentuk kegiatan belajar mengajar. Lokasi penelitian ini dibatasi hanya di SD Negeri 067245 Medan. Subjek penelitian ini adalah siswa Kelas IV yang dibatasi pada aspek kognitif mata pelajaran matematika pada tema Indahnya Negeriku materi Geometri bangun datar dan pengukuran. Penelitian ini melibatkan satu variabel bebas yaitu pendekatan pembelajaran tematik menggunakan video dan pendekatan pembelajaran menggunakan grafis konvensional, sedangkan variabel moderatornya adalah kemampuan spasial siswa yaitu kemampuan spasial visual tinggi dan kemampuan spasial visual rendah yang diperoleh dari hasil tes IQ (kemampuan Spasial
Dari latar belakang tersebut dapat dijelaskan bahwa perolehan hasil belajar masih rendah hal ini diduga disebabkan pendekatan pembelajaran yang masih konvensional sehingga kurang menarik minat dan kemauan siswa belajar dan penggunaan media yang juga masih sederhana serta konvensional.

Sebagai perbaikan perlu dilakukan penyelesaian masalah tersebut dengan mengadakan pendekatan pembelajaran tematik dengan menggunakan media pembelajaran menggunakan video yang berhubungan langsung dengan kemampuan spasial visual anak didik oleh karenanya maka diadakan penelitian pengaruh pendekatan pembelajaran tematik dengan menggunakan video dan kemampuan spasial visual terhadap hasil belajar matematika Sekolah Dasar.

Tujuan penelitian ini adalah: (1) Hasil belajar matematika yang diajar dengan pendekatan pembelajaran tematik mengunakan video lebih tinggi dari pada siswa yang diajar dengan pendekatan pembelajaran tematik menggunakan grafis konvensional. (2) Hasil belajar matematika siswa yang memiliki kemampuan spasial visual tinggi lebih tinggi dari pada siswa yang memiliki kemampuan spasial visual rendah. (3) Ada interaksi pendekatan pembelajaran tematik dengan menggunakan video dan kemampuan spasial visual terhadap hasil belajar matematika siswa.

visual), dan variabel terikatnya adalah hasil belajar matematika.

Pendekatan Penelitian yang digunakan menurut Meredith (2003:402) Quasi experiment adalah suatu penelitian yang menuntut peneliti memanipulasi dan mengendalikan satu atau lebih variabel bebas serta mengamati variabelvariabel terikat, untuk melihat perbedaan sesuai variabel bebas tersebut. Penelitian ini juga dapat diartikan sebagai sebuah penelitian yang ingin mengetahui sebab akibat dari perlakuan (treatment) kepada kelompok eksperimen. Pendekatan quasi experiment dilakukan terhadap dua kelompok yang dambil dari satu populasi dengan dua sampel yang terpisah. Kemudian kelas di bagi 2 lokal kelas A dan B dan dilakukan tes awal (pretest) pada keduanya untuk mendapatkan nilai. Setelah itu satu kelompok sampel dibiarkan berjalan seperti biasa dengan menggunakan pendekatan 
pembelajaran tematik grafis konvensional, yang lainnya diberi perlakuan dengan pendekatan pembelajaran tematik menggunakan video. Kemudian dalam penelitian ini dilakukan pengukuran untuk mengetahui kemampuan spasial visual siswa dan hasil belajar matematika siswa dengan pendekatan pembelajaran tematik mengunakan grafis konvensional dan pendekatan pembelajaran tematik mengunakan video. Kemudian dilaukan tes untuk mengambil hasil.

Sampel penelitian ini adalah cluster random sampling. Sampel yang diteliti terdiri dari 2 kelas yaitu Kelas IV-a dan Kelas IV-b dengan jumlah keseluruhan siswa adalah 70 orang. Setiap kelas memiliki karakteristik yang sama, artinya setiap kelas tidak memiliki siswa yang tinggal kelas, siswa memiliki rata-rata

\section{HASIL DAN PEMBAHASAN}

Hasil

Berdasarkan data skor tes hasil belajar Matematika siswa, langkah berikutnya adalah menghitung total skor dan rata-rata skor tiap kelompok perlakuan menurut Tabel Anava, umur yang tidak jauh berbeda secara signifikan, menggunakan kurikulum pendidikan yang sama. Disamping itu pembagian kelas tidak dilakukan berdasarkan rangking, sehingga tidak terdapat kelas unggulan yang karakteristik siswanya berbeda.

Penelitian ini menggunakan desain faktorial 2x2. Melalui desain ini akan dibandingkan pengaruh antara pendekatan pembelajaran tematik Menggunakan Video dan pendekatan pembelajaran tematik Menggunakan Grafis Konvensional terhadap hasil belajar matemtika ditinjau dari kemampuan spasial visual siswa yang tinggi dan kemampuan spasial visual siswa yang rendah yang akan mempengaruhi hasil belajar matematika siswa.

yang selanjutnya dapat digunakan sebagai dasar keputusan statistik untuk pengujian hipotesis, seperti pada Tabel sebagai berikut :

Tabel 1. Hasil Statistik Deskriptif

\begin{tabular}{|c|c|c|c|c|c|c|c|c|c|c|}
\hline \multirow{2}{*}{\multicolumn{2}{|c|}{$\begin{array}{c}\text { PPTM } \\
\text { KSV }\end{array}$}} & \multicolumn{6}{|c|}{ Pendekatan Pembelajaran Tematik Menggunakan } & \multirow{2}{*}{\multicolumn{3}{|c|}{ TOTAL }} \\
\hline & & & VII & & & & & & & \\
\hline \multirow{10}{*}{ 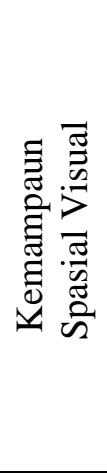 } & \multirow{5}{*}{$\begin{array}{l}\bar{O} \\
\mho \\
Z \\
\underline{G}\end{array}$} & $\mathrm{n}$ & $=$ & 17 & $\mathrm{n}$ & $=$ & 17 & $\mathrm{n}$ & $=$ & 34 \\
\hline & & $\Sigma \mathrm{X}$ & $=$ & 429 & $\Sigma X$ & $=$ & 383 & $\Sigma X$ & $=$ & 812 \\
\hline & & $\Sigma \mathrm{X}^{2}$ & $=$ & 10957 & $\Sigma X^{2}$ & $=$ & 8683 & $\Sigma X^{2}$ & $=$ & 19640 \\
\hline & & $\mu$ & $=$ & 25,24 & $\mu$ & $=$ & 22.53 & $\mu$ & $=$ & 23.88 \\
\hline & & $\mathrm{s}$ & $=$ & 2,86 & s & $=$ & 1.84 & $\mathrm{~s}$ & $=$ & 2.35 \\
\hline & \multirow{5}{*}{ 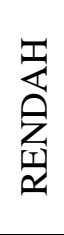 } & $\mathrm{n}$ & $=$ & 18 & $\mathrm{n}$ & $=$ & 18 & $\mathrm{n}$ & $=$ & 36 \\
\hline & & $\Sigma \mathrm{X}$ & $=$ & 265 & $\Sigma \mathrm{X}$ & $=$ & 271 & $\Sigma \mathrm{X}$ & $=$ & 536 \\
\hline & & $\Sigma \mathrm{X}^{2}$ & $=$ & 4011 & $\Sigma \mathrm{X}^{2}$ & $=$ & 4159 & $\Sigma \mathrm{X}^{2}$ & $=$ & 8170 \\
\hline & & $\mu$ & $=$ & 14.72 & $\mu$ & $=$ & 15.06 & $\mu$ & $=$ & 14.89 \\
\hline & & $\mathrm{s}$ & $=$ & 2.54 & $\mathrm{~s}$ & $=$ & 2.15 & $\mathrm{~s}$ & $=$ & 2.35 \\
\hline \multirow{5}{*}{\multicolumn{2}{|c|}{ TOTAL }} & $\mathrm{n}$ & $=$ & 35 & $\mathrm{n}$ & $=$ & 35 & $\mathrm{n}$ & $=$ & 70 \\
\hline & & $\Sigma X$ & $=$ & 694 & $\Sigma X$ & $=$ & 654 & $\Sigma X$ & $=$ & 1348 \\
\hline & & $\Sigma \mathrm{X}^{2}$ & $=$ & 14968 & $\Sigma \mathrm{X}^{2}$ & $=$ & 12842 & $\Sigma X^{2}$ & $=$ & 27810 \\
\hline & & $\mu$ & $=$ & 19.98 & $\mu$ & $=$ & 18.79 & $\mu$ & $=$ & 19.39 \\
\hline & & $\mathrm{s}$ & $=$ & 2.70 & $\mathrm{~s}$ & $=$ & 2.00 & $\mathrm{~s}$ & $=$ & 2.35 \\
\hline
\end{tabular}

Pengujian Hipotesis. Secara keseluruhan hasil Anava untuk pengujian hipotesis dapat dilihat pada Tabel 2. Berikut ini.

Tabel 2. Rangkuman Hasil Anava Secara Keseluruhan Terhadap Hasil Belajar Matematika 


\begin{tabular}{|l|c|c|c|c|c|c|}
\hline \multicolumn{1}{|c|}{ Sumber Varians } & $\mathrm{dk}$ & $\mathrm{JK}$ & $\mathrm{RJK}$ & $\mathrm{F}_{\text {hitung }}$ & $\mathrm{F}_{\text {tabel }}$ & Ket \\
\hline Media & 1 & 1414.29 & 1414.29 & 249.68 & 3,99 & Signifikan \\
\hline Kemampuan & 1 & 22.86 & 22.86 & 4.04 & 3,99 & Signifikan \\
\hline Interaksi & 1 & 40.38 & 40.38 & 7.13 & 3,99 & Signifikan \\
\hline Galat & 66 & 373.85 & 5.66 & & & \\
\hline Total & 69 & 1851.37 & & & & \\
\hline
\end{tabular}

Perbedaan Hasil Belajar Matematika Antara Siswa Yang Memperoleh Pendekatan Pembelajaran Tematik Menggunakan Video dan Grafis Konvensional. Adapun hipotesis statistik yang diuji adalah :

$$
\begin{aligned}
& \text { Ho }: \mu \mathrm{A}_{1} \leq \mu \mathrm{A}_{2} \\
& \mathrm{Ha}: \mu \mathrm{A}_{1}>\mu \mathrm{A}_{2}
\end{aligned}
$$

Berdasarkan hasil pengujian hipotesis pada tabel 4.13 di atas diperoleh $F_{\text {hitung }}$ sebesar 249,68 . Sementara nilai kritik $F_{\text {tabel }}$ dengan $d k$ $=(1,66)$ dan $\alpha=5 \%$ adalah sebesar 3,99. Hasil ini menunjukkan bahwa $F_{\text {hitung }}=249,68>\mathrm{F}_{\text {tabel }}=$ 3,95 sehingga Hipotesis Nol (Ho) ditolak, dengan demikian hipotesis penelitian yang menyatakan bahwa hasil belajar Matematika siswa yang dibelajarkan dengan Pendekatan Pembelajaran Tematik dengan Menggunakan Video lebih tinggi dari pada siswa yang diajarkan dengan Pendekatan Pembelajaran Tematik dengan Menggunakan Grafis Konvensional teruji kebenarannya.

Perbedaan Hasil Belajar Matematika Antara Siswa Yang Memiliki Kemampuan spasial visual Tinggi Dan Rendah. Adapun hipotesis statistik yang diuji adalah :

Ho : $\mu \mathrm{B}_{1}=\mu \mathrm{B}_{2}$

$\mathrm{Ha}: \mu \mathrm{B}_{1}>\mu \mathrm{B}_{2}$

Berdasarkan hasil pengujian hipotesis pada Tabel 4.13 di atas diperoleh $\mathrm{F}_{\text {hitung }}=4.04$ dan nilai kritik $\mathrm{F}_{\text {tabel }}$ dengan $\mathrm{dk}=(1,66)$ dan $\alpha=$ $5 \%$ adalah 3,99. Hasil ini menunjukkan bahwa $\mathrm{F}_{\text {hitung }}=4.04>\mathrm{F}_{\text {tabel. }}=3,99$ sehingga Hipotesis Nol (Ho) ditolak, dengan demikian hipotesis penelitian yang menyatakan bahwa siswa yang memiliki kemampuan spasial visual tinggi memperoleh hasil belajar Matematika yang lebih tinggi dari pada siswa yang memiliki kemampuan spasial visual rendah teruji kebenarannya.

Interaksi Antara Pendekatan Pembelajaran Tematik dan Kemampuan spasial visual Siswa Dalam Mempengaruhi Hasil Belajar Matematika. Adapun hipotesis statistik yang diuji adalah :

$$
\begin{aligned}
& \text { Ho }: \mathrm{A}><\mathrm{B}=0 \\
& \mathrm{Ha}: \mathrm{A}><\mathrm{B} \neq 0
\end{aligned}
$$

Berdasarkan hasil pengujian hipotesis di atas diperoleh $F_{\text {hitung }}=7.13$ dan nilai kritik $F_{\text {tabel }}$ dengan $\mathrm{dk}=(1,66)$ dan $\alpha=5 \%$ adalah 3,99 . Hasil ini menunjukkan bahwa $\mathrm{F}_{\text {hitung }}=7.13>$ $F_{\text {tabel. }}=3,99$ sehingga Hipotesis Nol (Ho) ditolak, dengan demikian hipotesis penelitian yang menyatakan bahwa terdapat interaksi antara pendekatan pembelajaran tematik dan kemampuan spasial visual dalam memberikan pengaruh terhadap hasil belajar Matematika teruji kebenarannya.

Karena ada interaksi antara pendekatan pembelajaran tematik dan kemampuan spasial visual dalam mempengaruhi hasil belajar Matematika, maka perlu dilakukan uji lanjutan (post hoc test), untuk mengetahui rata-rata hasil belajar sampel mana yang berbeda. Untuk melihat bentuk interaksi antara pendekatan pembelajaran tematik dan kemampuan spasial visual dalam mempengaruhi hasil belajar Matematika, dilakukan uji lanjut dengan menggunakan uji Scheffe'. Ringkasan hasil uji Scheffe' dapat dilihat pada Tabel 3. berikut :

Tabel 3. Ringkasan Hasil Perhitungan Uji Scheffe'

\begin{tabular}{|l|l|r|c|c|}
\hline \multicolumn{2}{|c|}{ Hipotesis Statistik } & \multirow{2}{*}{$\mathrm{F}_{\text {hitung }}$} & \multicolumn{2}{c|}{$\mathrm{F}_{\text {tabel }}$} \\
\cline { 4 - 5 } & & & $\alpha=5 \%$ & $\alpha=1 \%$ \\
\hline Ho $: \mu_{11}=\mu_{12}$ & Ha $: \mu_{11} \neq \mu_{12}$ & 16.23 & 2.74 & 4.09 \\
\hline Ho $: \mu_{11}=\mu_{21}$ & Ha $: \mu_{11} \neq \mu_{21}$ & 4.06 & 2.74 & 4.09 \\
\hline Ho $: \mu_{11}=\mu_{22}$ & Ha $: \mu_{11} \neq \mu_{22}$ & 15.71 & 2.74 & 4.09 \\
\hline Ho $: \mu_{12}=\mu_{21}$ & Ha $: \mu_{12} \neq \mu_{21}$ & 12.05 & 2.74 & 4.09 \\
\hline
\end{tabular}




\begin{tabular}{|l|l|r|r|l|}
\hline Ho $: \mu_{12}=\mu_{22}$ & Ha $: \mu_{12} \neq \mu_{22}$ & 0.53 & 2.74 & 4.09 \\
\hline Ho $: \mu_{21}=\mu_{22}$ & Ha $: \mu_{21} \neq \mu_{22}$ & 11.54 & 2.74 & 4.09 \\
\hline
\end{tabular}

Kriteria penerimaan jika : $F_{\text {hitung }}>F_{\text {tabel }}$, maka teruji secara signifikan. Dimana:

$\mu_{11}=$ rata-rata hasil belajar siswa yang diajar dengan pendekatan pembelajaran tematik menggunakan video dengan kemampuan spasial visual tinggi.

$\mu_{12}=$ rata-rata hasil belajar siswa yang diajar dengan pendekatan pembelajaran tematik menggunakan video dengan kemampuan spasial visual rendah.

$\mu_{21}=$ rata-rata hasil belajar siswa yang diajar dengan pendekatan pembelajaran tematik menggunakan grafis konvensional dengan kemampuan spasial visual tinggi.

$\mu_{22}=$ rata-rata hasil belajar siswa yang diajar dengan pendekatan pembelajaran tematik menggunakan grafis konvensional dengan kemampuan spasial visual rendah.

Berdasarkan hasil uji Scheffe' pada Tabel 3. di atas dapat dilihat bahwa terdapat 6 (enam) pasang hipotesis statistik, yakni :

a. Dari hasil perhitungan dengan menggunakan uji Scheffe' pada tabel di atas menunjukkan $\mathrm{F}_{\text {hitung }}=16.23>\mathrm{F}_{\text {tabel }}=2,74$, sehingga memberikan keputusan menolak Ho. Dengan demikian, hipotesis penelitian yang menyatakan bahwa hasil belajar Matematika siswa jika diajar menggunakan pendekatan pembelajaran tematik menggunakan video yang memiliki kemampuan spasial visual tinggi, lebih tinggi dibandingkan dengan pendekatan pembelajaran tematik menggunakan video untuk siswa yang memiliki kemampuan spasial visual rendah teruji kebenarannya.

b. Dari hasil perhitungan dengan menggunakan uji Scheffe' pada tabel di atas menunjukkan $\mathrm{F}_{\text {hitung }}=4,06>\mathrm{F}_{\text {tabel }}=2,74$, sehingga memberikan keputusan menolak Ho. Dengan demikian, hipotesis penelitian yang menyatakan bahwa hasil belajar Matematika siswa jika diajar menggunakan pendekatan pembelajaran tematik menggunakan video yang memiliki kemampuan spasial visual tinggi, memiliki kemampuan lebih tinggi dibandingkan pendekatan pembelajaran tematik menggunakan grafis konvensional untuk siswa yang memiliki kemampuan spasial visual tinggi teruji kebenarannya. c. Dari hasil perhitungan dengan menggunakan uji Scheffe' pada tabel di atas menunjukkan $\mathrm{F}_{\text {hitung }}=15,71>\mathrm{F}_{\text {tabel }}=2,74$, sehingga memberikan keputusan menolak Ho. Dengan demikian, hipotesis penelitian yang menyatakan bahwa hasil belajar Matematika siswa jika diajar menggunakan pendekatan pembelajaran tematik menggunakan video yang memiliki kemampuan spasial visual tinggi, lebih tinggi dibandingkan dengan pendekatan pembelajaran tematik menggunakan grafis konvensioanl untuk siswa yang memiliki kemampuan spasial visual rendah teruji kebenarannya.

d. Dari hasil perhitungan dengan menggunakan uji Scheffe' pada tabel di atas menunjukkan $\mathrm{F}_{\text {hitung }}=12,05>\mathrm{F}_{\text {tabel }}=2,74$, sehingga memberikan keputusan menolak Ho. Dengan demikian, hipotesis penelitian yang menyatakan bahwa hasil belajar Matematika siswa jika diajar menggunakan pendekatan pembelajaran tematik menggunakan grafis konvensional yang memiliki kemampuan spasial visual tinggi, lebih tinggi dibandingkan dengan pendekatan pembelajaran tematik menggunakan video untuk siswa yang memiliki kemampuan spasial visual rendah teruji kebenarannya.

e. Dari hasil perhitungan dengan menggunakan uji Scheffe' pada tabel di atas menunjukkan $\mathrm{F}_{\text {hitung }}=0,53<\mathrm{F}_{\text {tabel }}=2,74$, sehingga memberikan keputusan menerima Ho. Dengan demikian, hipotesis penelitian yang menyatakan bahwa hasil belajar Matematika siswa jika diajar menggunakan pendekatan pembelajaran tematik menggunakan grafis konvensional yang memiliki kemampuan spasial visual rendah, memiliki kemampuan yang sama dibandingkan dengan pendekatan pembelajaran tematik menggunakan video untuk siswa yang memiliki kemampuan spasial visual rendah teruji kebenarannya.

f. Dari hasil perhitungan dengan menggunakan uji Scheffe' pada tabel di atas menunjukkan $\mathrm{F}_{\text {hitung }}=11,54>\mathrm{F}_{\text {tabel }}=2,74$, sehingga memberikan keputusan menolak Ho. Dengan demikian, hipotesis penelitian yang menyatakan bahwa hasil belajar Matematika siswa jika diajar menggunakan pendekatan pembelajaran tematik menggunakan grafis 
konvensional yang memiliki kemampuan spasial visual tinggi, lebih tinggi dibandingkan dengan pendekatan pembelajaran tematik menggunakan video untuk siswa yang memiliki kemampuan spasial visual rendah teruji kebenarannya.
Selanjutnya adanya interaksi antara variabel strategi pembelajaran dan komunikasi interpersonal terhadap hasil belajar Matematika siswa, maka perlu diberikan gambaran grafik estimasi yang menunjukkan adanya interaksi tersebut.

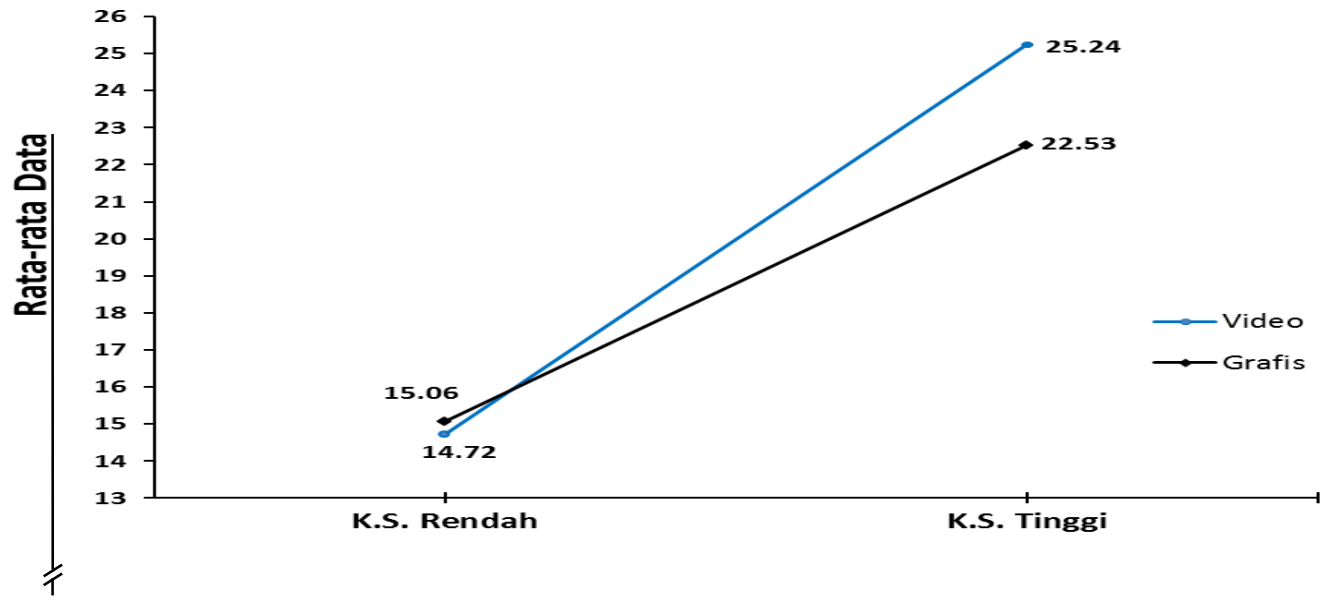

Gambar 1. Model Interaksi Antara Pendekatan Pembelajaran Tematik Menggunakan Video dan Kemampuan Spasial Visual Terhadap Hasil Belajar Matematika Siswa

\section{Pembahasan}

Hasil belajar matematika siswa yang diajar dengan pendekatan pembelajaran tematik dengan menggunakan video lebih tinggi dari pada siswa yang diajar dengan pendekatan pembelajaran tematik menggunakan grafis konvensional. Hasil penelitian ini telah menunjukkan bahwa terdapat perbedaan hasil belajar matematika antara siswa yang diajar dengan pendekatan pembelajaran tematik dengan menggunakan video dan pendekatan pembelajaran tematik dengan menggunakan grafis konvensional, dimana nilai rata-rata matematika siswa yang diajar dengan pendekatan pembelajaran tematik dengan menggunakan video lebih tinggi daripada siswa yang diajar dengan pendekatan pembelajaran tematik dengan menggunakan grafis konvensional, dimana $f_{\text {hitung }}>f_{\text {tabel }}=249,68>$ 3,99 .

Kenyataan ini membuktikan bahwa bahwa menggunakan pendekatan pembelajaran tematik dengan menggunakan video lebih baik dalam meningkatkan pemahaman siswa dalam pembelajaran matematika daripada penggunaan pendekatan pembelajaran tematik dengan menggunakan grafis konvensional. Dengan demikian mengajarkan matematika akan lebih baik dengan menggunakan pendekatan pembelajaran tematik dengan menggunakan video dibanding dengan menggunakan pendekatan pembelajaran tematik dengan menggunakan grafis konvensional.

Matematika merupakan mata pelajaran yang sangat penting untuk mengembangkan kemampuan berhitung, mengukur, menurunkan rumus dan menggunakan rumus matematika yang diperlukan dalam kehidupan sehari-hari melalui pengukuran dan geometri, aljabar, peluang dan statistika, kalkulus dan trigonometri. Metematika juga berfungsi mengembangkan kemampuan mengkomunikasikan gagasan melalui model matematika, diagram, grafik, atau tabel.

Mata pelajaran matematika bertujuan agar peserta didik memiliki kemampuan sebagai berikut: 1. Memahami konsep matematika, menjelaskan keterkaitan antar konsep dan mengaplikasikan konsep atau algoritma, secara luwes, akurat, efisien, dan tepat, dalam pemecahan masalah; 2. Menggunakan penalaran pada pola dan sifat, melakukan manipulasi matematika dalam membuat generalisasi, menyusun bukti, atau menjelaskan gagasan dan pernyataan matematika; 3 . Memecahkan masalah yang meliputi kemampuan memahami masalah, merancang model matematika, menyelesaikan model dan menafsirkan solusi yang diperoleh; 4. Mengomunikasikan gagasan dengan simbol, tabel, diagram, atau media lain untuk 
memperjelas keadaan atau masalah; 5. Memiliki sikap menghargai kegunaan matematika dalam kehidupan, yaitu memiliki rasa ingin tahu, perhatian, dan minat dalam mempelajari matematika, serta sikap ulet dan percaya diri dalam pemecahan masalah.

Pembelajaran pendidikan Matematika akan memberikan perolehan hasil belajar yang lebih baik melalui pendekatan pembelajaran tematik dengan mengguanakan media, yakni pembelajaran yang mengaitkan antara kesiapan struktur kognitif atau pengalaman belajar dengan menggunakan media. pengetahuan baru yang akan diterima siswa dengan cara menciptakan lingkungan belajar yang merangsang untuk pembelajaran kreatif. Matematika adalah mata pelajaran yang sangat kompleks dan sangat dibutuhkan dalam kehidupan manusia, mata pelajaran matematika bertujuan agar peserta didik memiliki kemampuan berikut: 1) Memahami konsep matematika, menjelaskan keterkaitan antarkonsep dan mengaplikasikan konsep atau algoritma, secara luwes, akurat, efisien, dan tepat, dalam pemecahan masalah. 2) Menggunakan penalaran pada pola dan sifat, melakukan manipulasi matematika dalam membuat generalisasi, menyusun bukti, atau menjelaskan gagasan dan pernyataan matematika. 3) Memecahkan masalah yang meliputi kemampuan memahami masalah, merancang model matematika, menyelesaikan model dan menafsirkan solusi yang diperoleh. 4) Mengomunikasikan gagasan dengan simbol, tabel, diagram, atau media lain untuk memperjelas keadaan atau masalah

Dengan melihat luasnya cakupan dan objek pelajaran Matematika, maka dibutuhkan siswa yang mampu untuk membangun atau mengkonstruk sendiri pengetahuan dan keterampilan yang dibutuhkan untuk memecahkan masalah-masalah belajarnya. Di samping itu siswa harus menemukan sendiri pengetahuan dan keterampilan tersebut, dan bukan karena diberitahukan oleh gurunya. Siswa mampu belajar secara aktif dan mandiri dengan mengembangkan atau menggunakan gagasan-gagasan dalam menyelesaikan masalah pembelajaran. Dengan demikian, pengetahuan dan keterampilan akan dapat diingat dan dipahami dalam memori jangka panjang, dan sewaktu-waktu dapat digunakan sesuai dengan kebutuhan belajar siswa.

Dari uraian di atas, dapat dipahami bahwa hasil belajar Matematika siswa yang diajar dengan pendekatan pembelajaran tematik menggunakan video lebih tinggi dari pada siswa yang dibelajarkan dengan pendekatan pembelajaran tematik menggunakan grafis konvensional.

Hasil belajar matematika siswa yang memiliki Kemampuan spasial visual Tinggi lebih tinggi dari pada siswa yang memiliki Kemampuan spasial visual Rendah. Hasil penelitian ini telah menunjukkan bahwa siswa yang memiliki kemampuan spasial visual tinggi memperoleh nilai rata-rata hasil belajar matematika yang lebih tinggi dibandingkan dengan siswa yang memiliki kemampuan spasial visual rendah, dengan $f_{\text {hitung }}>f_{\text {tabel }}=4,04$ $>3,99$.

Selanjutnya dalam penelitian ini juga terbukti bahwa hasil belajar matematika siswa yang memiliki kemampuan spasial visual tinggi yang diajarkan dengan pendekatan pembelajaran tematik menggunakan video lebih tinggi daripada hasil belajar matematika siswa yang memiliki kemampuan spasial visual tinggi yang diajarkan dengan pendekatan pembelajaran tematik grafis konvensional. Hal ini berindikasi bahwa siswa yang mempunyai kemampuan spasial visual tinggi lebih mampu memahami materi ajar matematika dibandingkan dengan siswa yang memiliki kemampuan spasial visual rendah. Penelitian ini juga membuktikan bahwa siswa yang memiliki kemampuan spasial visual tinggi lebih cocok diajarkan dengan pendekatan tematik menggunakan video.

Oleh karena itu dapat dijelaskan, bagi kelompok siswa yang memiliki kemampuan spasial tinggi terhadap matematika yang tinggi, lebih tepat diberikan penedekatan pembelajaran tematik dengan menggunakan video dari pada grafis konvensional. Hal ini disebabkan karena pada dasarnya pendekatan pembelajaran tematik dengan menggunakan video memacu siswa untuk lebih meningkatkan hasil belajar matematika yang lebih tinggi.

Sedangkan bagi kelompok siswa yang memiliki kemampuan spasial/visual rendah, lebih tepat diberikan pendekatan pembelajaran tematik dengan menggunakan grafis konvensional dari pada pendekatan pembelajaran dengan menggunakan video. Hal ini disebabkan pada dasarnya pendekatan pembelajaran tematik dengan menggunakan grafis konvensional kurang mengaktifkan siswa untuk belajar sungguh-sungguh dan kurang merangsang kemampuan spasial/visual siswa untuk belajar secara sungguh-sungguh dan kurang merangsang kemampuan spasial/visual 
siswa untuk meningkatkan hasil belajar matematika sehingga hasil belajar matematika siswa rendah.

Pendekatan pembelajaran tematik dengan menggunakan video akan mempengaruhi kemampuan spasial/visual tinggi dan dapat menghasilkan hasil belajar matematika yang tinggi pula. Sedangkan pengaruh pendekatan pembelajaran tematik dengan menggunakan grafis konvensional akan mempengaruhi kemampuan spasial/visual rendah dan menghasilkan hasil belajar matematika tinggi pula.

Sebaliknya karena pengaruh pendekatan pembelajaran tematik dengan menggunakan video dapat menghasilkan kemampuan spasial tinggi terhadap matematika dan menghasilkan hasil belajar matematika tinggi maka dapat diduga bahwa pengaruh pendekatan pembelajaran tematik dengan menggunakan video sangat tepat untuk mencerdaskan siswa yang mempunyai kemampuan spasial/visual rendah menjadi siswa yang mempunyai kemampuan spasial/visual tinggi dan menghasilkan hasil belajar matematika yang tinggi pula.

Pembelajaran dengan pendekatan tematik dengan menggunakan video juga lebih baik dibandingkan dengan pendekatan tematik dengan menggunakan grafis konvensional untuk diterapkan kepada siswa yang memiliki kemampuan spasial visual tinggi.

Karakteristik siswa yang memiliki kemampuan spasial antara lain: 1) Memberikan gambaran visual yang jelas ketika menjelaskan sesuatu; 2) Mudah membaca peta atau; 3) Menggambar sosok orang atau benda mirip dengan aslinya; 4) Sangat menikmati kegiatan visual, seperti teka-teki atau sejenisnya; 5) Mencoret-coret di atas kertas atau buku tugas sekolah; dan 6) Lebih memahami informasi lewat gambar daripada kata-kata atau uraian. 7) mempunyai keinginan yang kuat untuk bertanggungjawab pada dirinya dalam menyelesaikan masalah dan tugas-tugas yang dibebankan padanya,. 8) mempunyai kecenderungan untuk menetapkan tujuan prestasi yang lebih sulit dan menghitung resiko-

\section{PENUTUP}

\section{Simpulan}

Simpulan-simpulan yang dapat ditarik dari hasil pengujian hipotesis adalah sebagai berikut:

Pertama, terdapat perbedaan hasil belajar Matematika siswa yang dibelajarkan dengan resikonya. 9) mempunyai keinginan yang kuat untuk berkonsentrasi dalam tugas-tugas. 10) berpikir dalam menyelesaikan tugas.

Terdapat interaksi antara pendekatan pembelajaran tematik menggunakan video dan Kemampuan spasial visual terhadap hasil belajar matematika siswa. Hasil penelitian ini telah menunjukkan bahwa terdapat interaksi antara pendekatan pembelajaran tematik menggunakan media (video dan grafis konvensional) dan kemampuan spasial visual dalam mempengaruhi hasil belajar matematika siswa. Pendekatan pembelajaran tematik dengan menggunakan video akan mempengaruhi kemampuan spasial/visual tinggi dan dapat menghasilkan hasil belajar matematika yang tinggi pula. Sedangkan pengaruh pendekatan pembelajaran tematik menggunakan grafis konvensional akan mempengaruhi kemampuan spasial/visual rendah dan menghasilkan hasil belajar matematika rendah pula.

Sebaliknya karena pengaruh pendekatan pembelajaran tematik menggunakan video dapat menghasilkan kemampuan spasial tinggi terhadap matematika dan menghasilkan hasil belajar matematika tinggi maka dapat dibuktikan bahwa pengaruh pendekatan pembelajaran tematik dengan menggunakan video sangat tepat untuk mencerdaskan siswa yang mempunyai kemampuan spasial/visual rendah menjadi siswa yang mempunyai kemampuan spasial/visual tinggi dan menghasilkan hasil belajar matematika yang tinggi pula.

Dari paparan di atas dapat dibuktikan bahwa terdapat interaksi antara pengaruh pendekatan pembelajaran tematik dengan kemampuan spasial terhadap hasil belajar matematika, dengan $f_{\text {hitung }}>f_{\text {tabel }}=7,13>3,99$ sehingga terdapat interaksi yang signifikan.

Dari uraian di atas, dapat dipahami bahwa terdapat interaksi antara pendekatan pembelajaran tematik dengan menggunakan (video dan gafis konvensional) dan kemampuan spasial visual dalam mempengaruhi hasil belajar Matematika siswa.

Pembahasan

Pendekatan Pembelajaran Tematik dengan Menggunakan Video lebih tinggi dari pada siswa yang diajarkan dengan Pendekatan Pembelajaran Tematik dengan Menggunakan Grafis Konvensional. Dengan demikian 
Pendekatan Pembelajaran Tematik dengan Menggunakan Video lebih efektif diterapkan dalam pembelajaran matematika guna meningkatkan hasil belajar siswa.

Kedua, rata-rata hasil belajar Matematika siswa yang memiliki kemampuan spasial visual tinggi lebih tinggi dibandingkan siswa yang memiliki kemampuan spasial visual rendah.

Ketiga, hasil perhitungan analysis varians menunjukkan bahwa terdapat interaksi antara pendekatan pembelajaran tematik menggunakan media (video dan grafis konvensional) dan

\section{Saran}

Berdasarkan simpulan hasil penelitian, implikasi, dan keterbatasan penelitian, maka dikemukakan saran-saran sebagai berikut:

1. Untuk pensosialisasian penggunaan pendekatan pembelajaran tematik dengan menggunakan video hendaknya dilakukan seminar-seminar ataupun pelatihan-pelatihan bagi guru-guru agar dijadikan sebagai salah satu alternative dalam menyampaikan pelajaran.

2. Kepada pengawas TK/SD ataupun rumpun mata pelajaran matematika agar terlebih dahulu menguasai seluk beluk pendekatan pembelajaran tematik dengan menggunakan media video yang hendak diberikan kepada guru-guru (guru kelas dan guru matematika)

3. Kepada guru matematika dan guru kelas agar benar-benar memperhatikan berbagai pendekatan pembelajaran dan media pembelajaran serta kemampuan (kemampuan) tertentu siswa sebelum melakukan pengukuran terhadap kemampuan serta hasil belajar siswa.

\section{DAFTAR PUSTAKA}

Armstrong, T. (2013). Kecerdasan Multiple didalam Kelas. Jakarta. Indeks

Arsyad, Azhar. (2007) Media Pembelajaran. Jakarta: Raja Grafindo Persada

Arikunto, Suharsimi. (2013) Manajemen Penelitian. Jakarta. Rineka Cipta

Amri, Sofan. (2013) Pengembangan Model Pembelajaran dalam Kurikulum 2013. Jakarta. Prestasi Pustaka Publisher

B. Uno, Hamzah. (2004). Model Pembelajaran. Gorontalo: Nurul Jannah (2006). Orientasi Baru Dalam Psikologi Pembelajaran. Jakarta: Bumi Aksara kemampuan spasial visual dalam mempengaruhi hasil belajar matematika siswa, sehingga siswa dengan kemampuan spasial visual tinggi lebih baik diajar dengan menggunakan pendekatan pembelajaran tematik dengan menggunakan video, sedangkan siswa dengan kemampuan spasial visual rendah lebih baik diajar dengan menggunakan pendekatan pembelajaran tematik dengan menggunakan grafis konvensional.

4. Kepada pihak penulis/pengarang buku matematika agar mencantumkan pendekatan pembelajaran tematik dengan menggunakan media pembelajaran video dalam penerbitan buku berikutnya.

5. Kepada peneliti lain yang ingin meneliti lebih lanjut tentang pendekatan pembelajaran tematik dengan menggunakan video hendaknya memperluas jumlah sampel dan menambah variable-variabel yang dikontrol sehingga diperoleh pengetahuan yang lebih luas lagi mengenai pendekatan dan media pembelajaran terhadap kemampuan (kemampuan) siswa, menambah waktu penelitian baik dalam tes maupun pembelajaran, serta menambah variasi media yang digunakan dalam penerapan pendekatan pembelajaran seperti: media computer, media televisi, media laptop, dalam pendekatan pembelajaran yang menerapkan project based learning atau discovery based learning.

. (2010). Mengelola Kecerdasan Dalam Pembelajaran. Jakarta: Bumi Aksara

Bishop, Alan J. (1988) Matemathics Education And Culture. Boston. Kluwer Academic Publisher

C, Sprinthall, Richard. (1991) Understanding Educational Research. New Jersey. Prentice Hall

Djamarah, Syaiful Bahri. (2010). Guru dan Anak Didik Dalam Interaksi Edukatif. Jakarta. Rineka Cipta

Dahar, Ratna Willis. (2011) Teori-Teori Belajar dan Pembelajaran. Jakarta. Erlangga 
Djamarah, Syaiful Bahri. (2010). Psikologi Belajar. Jakarta. Rineka Cipta

E.Gredler, Margaret. (2011) Learning and Instruction. Teori dan Aplikasi. Jakarta. Kencana

Gardner, Howard. (2007) The Theory of Multiple Intelligences. New York. Basic Books,

Garner, Howard. (2010) The Theory of Multiple Intelligence. New York. Basic Books.

Heruman. (2008) Model Pembelajaran Matematika Di Sekolah Dasar. Bandung. Rosdakarya

Hamdi K, Abdul. (2009) Teori Belajar dan Pembelajaran.

Ibnu Hajar. (2013) Panduan Kurikulum Tematik Untuk SD. Jogjakarta. Diva Pres

Kusmayadi, Ismail. (2011) Membongkar Anak Cerdas. Jakarta. Gudang Ilmu

La Iru. (2012) Analisis Pendekatan, Metode, Strategi, dan Model-Model Pembelajaran. Bantul DIY. Multi Presindo

Lwin, May. (2008). Cara Mengembangkan Berbagai Komponen Kecerdasan. Jakarta: Indeks.

Meredith. (2003) Educational Research An Introduction. Boston New York. AB

Meguels, Nancy. (2008) Pemikiran Visual. PT. Indeks

Miarso, Yusufhadi. (2004). Menyemai Benih Teknologi Pendidikan. Jakarta: Prenada Media
Nuh, Muhammad. (2013) Menyambut Kurikulum 2013. Jakarta. Buku Kompas

Sudijono, Anas. (2013) Evaluasi Pendidikan. Jakarta. Raja Grafindo Persada

Smaldino, dkk. (2011) Intructional Technology \& Media For Learning. Jakarta. Kencana Pranada Media Group

Schunk, Dale H. (2012) Learning Theories An Educational Perspective. Jogjakarta. Pustaka Pelajar

Sudijono. (2011) Pengantar Evaluasi Pendidikan. Jakarta. Raja Grafindo Persada

Sudjana, (2001). Metoda Statistika. Bandung. Tarsito

Sukmadinata, Nana Syaodih. (2204) Landasan Psikologi Proses Pendidikan. Bandung. Remaja Roskadarya

Sundayana, Rostina. (2013) Media Pembelajaran Matematika. Bandung. Alfabeta

Van De Walle, John. (2007) Matematika Sekolah Dasar dan Menengah Pengembangan Pengajaran. Jakarta. Erlangga

W. Santrock, John, (2007) Psikologi Pendidikan. Jakarta. Kencana

Wijanarko, Jarot. (2012). Anak Cerdas. Banten: Happy Holy Kids

http://matematikalujeng.blogspot.com/2013/02/t ujuan-pembelajaran-matematikasekolah.html, Rabu, 18 Juni 2014. Pukul $12.74 \mathrm{am}$. 